\title{
Degradation behaviour of magnesium alloy and its composite used as a biomaterial
}

\author{
Sandeep Kumar Jhamb*1, Ashish Goyal ${ }^{1}$, Anand Pandey $^{1}$,Jay Marwaha ${ }^{1}$, Jay Matai ${ }^{1}$ \\ ${ }^{1}$ Department of Mechanical Engineering, Manipal University Jaipur, Dehmi Kalan, Jaipur, Rajasthan, India, 303007
}

\begin{abstract}
In the last six decades, it has been made a great advancement in the field of engineering material especially in biomaterials, including metal alloys, composites, polymers, ceramics, and metallic glasses. Different form of these biomaterial are used as a engrafts. Unlike conventional materials such as stainless steel, cobalt, or titanium-based alloy resulting in stress shielding effect, some of these materials are designed in such a way to degrade or to be resorbed inside the body rather than removing the implant after its function is served. Here, Magnesium based biomaterials are the most suitable and used as a newly developed biodegradable material. Inherent mechanical properties of magnesium like properties of elastic and modulus rigidity which are very much same as to those of human bone, make it biocompatible. There is limited use of pure $\mathrm{Mg}$ due to its corrosive nature, but when formed an alloy or the composite the degradation property can be improved and making them a material of choice for implantation. This paper aim is to review the degradation rate and the methods to control it. Due to high degradation rate of the $\mathrm{Mg}$, as compare to other biomaterials, our final goal is to maintain the balance between the gradual loss of material and mechanical strength during degradation, by providing the strength to the newly forming bone tissue. Mg-based alloy or composite has the potential to be used as a biomaterial without the need for a second surgery, once this goal is achieved.
\end{abstract}

\section{Introduction}

At present, about 2.8 million demand for bone repair and implant cases are performed annually worldwide. Commonly biomaterials have faced the problem of fatigue, erosion, and corrosion. The biomaterial properties are important for accepted osseointegration. For any type of engraft, permanent or temporary the most important properties which are taken into consideration are biocompatibility and mechanical endurance [5]. When two or different implants are combined, corrosion resistance is important. Degradation rate is also an important factor for biodegradable material. Implant material should be lightweight to simplify motion. Implant materials should also have analogous characteristics as a bone. When the implant material is come into the contact with extracellular fluid, blood and soft tissues, it must be biological stable in vitro condition in addition to its mechanical properties. Therefore, the implant material should have similar properties as of human bone like mechanical properties, its biocompatibility, high corrosion, and wear resistance, and which enable osseointegration [3-7]. Polymer, ceramic, metal and their composites are mostly used as a biomaterial. At present conventional material like cobalt-chromium stainless steel, and titanium, are generally used [20].

\footnotetext{
* Corresponding author: rpsjhamb@gmail.com
}

Due to high mechanical strength and fracture toughness, metallic materials play an important role as a biomaterial to assist the healing or replace bone tissue that is diseased or damage as compare to polymer and ceramic materials. Therefore, metallic materials having the huge scope in the field of implant [10-12].

The materials that are used in temporary engraft can be moderately terminate and can be evacuated from the body of the human. As soon as the healing process is outright this biodegradable engrafts do not require a subsequent surgery. The central summons is to plan and adjust the rate of degradation to fit in a particular implementation. The by-products from the degradation should not evoke swelling and any other unpleasant effect. Those temporary engrafts are in huge demand, which is easily degradable and tarnished in biological environment. These characteristics can prevent the longlasting problem of permanent engraft and do not required subsequent surgery. The best degradable engraft should provide good physiologic mend, renovation of local acquiescence, a interim brace of the damaged tissue, and the probability for flourishing and positive modification at later stage. Furthermore, it must be reconcilable with the resultant procedure and not limit to restore blood flow to any organ [21]. Medication and heritable transfer should be given specially for the stent material. Since an engraft requires to work 
completely for the time interval until the area which undertakes the surgery starts.

Presently, many of the researchers are mostly working on the development of the biocompatible material, which should also be a biodegradable and should not cause any type of inflammatory reaction.

Design, material constitute and surface properties like surface texture, surface chemistry and surface energy have great influence on implant interaction phenomena, including the biocompatibility of the implant material [22].

In the 1930s the first-ever study on the practicability of $\mathrm{Mg}$ material engrafts for the bone fixtures, showing magnificent restorability and biocompatibility. Although the evolution of hydrogen gas is injurious if release in quantity. However, hydrogen evolution generally not play a significant role in small-scale engraft like stents, it can cause a problem when dealing with big parts required to brace osteosynthesis. The hydrogen bubbles can cause gas voids near mg engrafts in the flesh of humans because of the collection of hydrogen and insufficient transport mechanism. To avoid the risk of osteosynthesis hydrogen bubbles can be detached by penetrating. Therefore, it is better to prevent the hydrogen gas bubble formation [26].

The research is more concentrated on polymer and metal-based biodegradable material. Due to greater mechanical firmness and their corrosion by-products evoke less critical inflammation. For the usage in cardiovascular interference and osteosynthesis, magnesium and iron can be taken into consideration. Iron possesses low corrosion rates. Hence, for the orthopaedic engraft magnesium alloys have been significantly used and are very biocompatible.

The main problem possesses by using the conventional steel and titanium material is that it couldn't help in minimizing the stress shielding due to its high modulus, which can finally carry the majority of the load placed on the implant and bone, further this problem can easily overcome by the use of low modulus magnesium [28-30]. The outside load is necessary for the formation of a new bone structure. In bone fracture treatment stress shielding effect creates complications. If the transplant made of magnesium is used for fracture fixation, it reduces the stress shielding effect due to the property of low modulus possess by magnesium which is near to the modulus bone [20]. Therefore, magnesium and its alloy and composite has been highly recommended as a suitable base material for osteosynthesis process.

Now, we need to develop such a biomaterial which should be fulfil the requirement of biodegradability in the body fluid and having the similar mechanical properties, especially elastic modulus property is very similar to human bone as compare to other metal. Metals, like magnesium, zinc and iron are found to be a degradable in the human body fluids and having the good biocompatibility revealed by many researchers. Additionally, Magnesium is having a very similar elastic modulus that is $41-45 \mathrm{GPa}$ as compare to human bone i.e. 10-20 GPa [29]. The main limitation with iron used as an implant is its very low degradation rate or non- degradable nature and collection of by product iron hydroxide particles in many tissues. For the Zinc also slow degradation in the body fluid is limits its uses for temporary orthopaedic, application as it takes several years to complete full degradation. Calcium, Zinc Aluminium etc are used to make the magnesium alloy. These magnesium alloys can be further strengthened by solid solution, uniform dispersion, and precipitation hardening [25]. Magnesium metal matrix composites are now introduced as a new generation material in the area of orthopaedic engraft.

\section{Biodegradability}

Biodegradability is an ability of the material by which it can be degraded completely and safely without leaving any type harmful residues. Those material which are used as a biodegradable implant is that they do degrade after fulfilled their function, so that second surgery is not necessary to remove the implant. As the implant material degraded, it loses its mechanical properties and new grown bone stimulated with increasing load on healing tissue shown in fig 1 . Recovery rate of bone tissue matches with the degradation rate of implant; therefore, it is necessary to investigate the mechanism, their behaviour and methods to regulate the degradation rate [30]

\subsection{Degradable mechanisms}

Principles of electrochemical are generally used to explain the mechanism of degradation for metallic implants. Following are the reactions which are involves during the degradation process of magnesium alloy and the main degradation products are $\mathrm{H}_{2}$ and $\mathrm{Mg}(\mathrm{OH})_{2}$ [30].

$$
\begin{aligned}
& \text { Reaction at Anode } \mathrm{Mg} \rightarrow \mathrm{Mg}^{+2}+2 e \text {-----(1) } \\
& \text { Reaction at Cathode } 2 \mathrm{H}_{2} \mathrm{O}+2 e \rightarrow \mathrm{H}_{2} \uparrow+2 \mathrm{OH} \text {-----(2) } \\
& \text { Therefore } \mathrm{Mg}+2 \mathrm{H}_{2} \mathrm{O} \rightarrow \mathrm{Mg}(\mathrm{OH})_{2}+\mathrm{H}_{2} \uparrow---(3)
\end{aligned}
$$

Now this Magnesium hydroxide on the surface of base metal i.e. Mg-based alloys is easily get eroded by body fluid which contain chlorine ions as per following reaction:

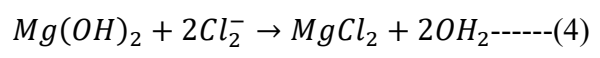

Thus, this magnesium oxide layer can't act as the protective layer fig 2 against the corrosion by which it accelerates the degradation rate. Composition and the structural states of the magnesium alloy decide the type of degradation. Here it starts the pitting corrosion which is usually undesirable because of which this $\mathrm{MgCl}_{2}$ is come in contact with implant metal and become the reason to start the galvanic corrosion which further accelerate the degradation and there is significant reduction in the mechanical strength of implant. 


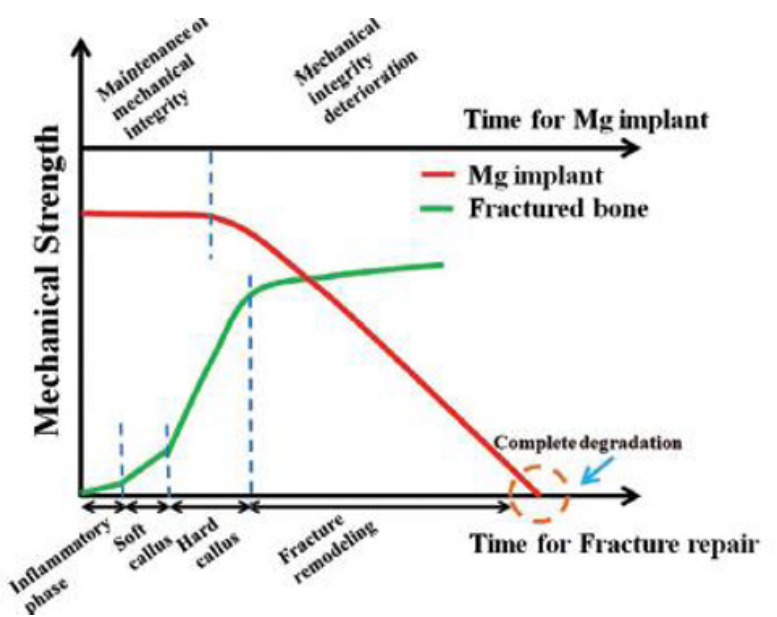

Fig 1 (a) Bone healing \& Mg Implant

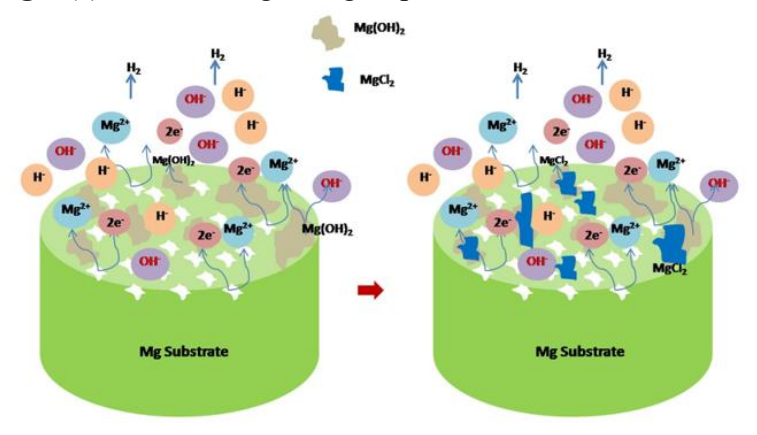

Fig. 1. (b) Degradation behavior

According to the anodic reaction biodegradable metal release the electron and then oxidized to metal ions $\left(\mathrm{Mn}^{+}\right)$. Now this metal ion take part in cathodic reaction and result in local alkalization. Body fluid containing the $\mathrm{Cl}^{-1}$ ions are responsible for the erosion of the degradation layer of $\mathrm{M}(\mathrm{OH})_{\mathrm{n}}$ form on the metal surface. For cell adhesion, apatite is required which is formed by the local alkalization due to presence of $\mathrm{Ca}^{2+}$ and $\mathrm{PO}_{4}{ }^{3-}$ ions present in the body fluid. As the cells are reproduce gradually, new tissues will be formed on the metal surface, as the time passes. This process is continuously be going on and as a result more degradation products are formed due to fall of the metal matrix and continue dissolve of metal matrix on the body fluid, further new fresh matrix expose to the body fluid and the process undergoes a new degradation [24]. The formation of the new apatite layer was occurred as per following equations.

$$
\begin{aligned}
\mathrm{Ca}^{+2}+\mathrm{HPO}_{4}^{-2} & \rightarrow \mathrm{CaHP}_{4}----(5) \\
4 \mathrm{Ca}^{+2}+\mathrm{HPO}_{4}^{-2}+2 \mathrm{PO}_{4}^{-3} & \rightarrow \mathrm{Ca}_{4}\left(\mathrm{HPO}_{4}^{-2}\right)\left(\mathrm{PO}_{4}^{-3}\right)_{4}----(6) \\
5 \mathrm{Ca}^{+2}+3 \mathrm{PO}_{4}^{-3}+\mathrm{OH}^{-} & \rightarrow \mathrm{Ca}_{5}\left(\mathrm{PO}_{4}\right)_{3}(\mathrm{OH})-------(7)
\end{aligned}
$$

The Apatite dissolution can be shown by Eqs. (8) and (9) as follow

$$
\begin{gathered}
\mathrm{Ca}_{5}\left(\mathrm{PO}_{4}\right)_{3}(\mathrm{OH}) \rightarrow 5 \mathrm{Ca}^{+2}+3 \mathrm{PO}_{4}^{-3}+\mathrm{OH}^{-}-----(8) \\
\mathrm{Ca}_{5}\left(\mathrm{PO}_{4}\right)_{3}(\mathrm{OH})+7 \mathrm{H}^{+} \leftrightarrow 4 \mathrm{Ca}^{+2}+\mathrm{HPO}_{4}^{-}+\mathrm{H}_{2} \mathrm{O}----(9)
\end{gathered}
$$

\section{Conventional biomaterial}

\subsection{Stainless steel (316L)}

The main limitation of SS $316 \mathrm{~L}$ is its less biocompatibility because of the presence of nickel which also cause allergic reactions, being a low resistance to corrosion its usage in temporary implant is limited [14]. SS 316L is having good mechanical strength property, elastic property, ductility and easily manufacturability, and easily available at low cost.

\subsection{Co-Cr metallic alloy}

Co-Cr metallic alloy replaced the SS 316L because of its very high corrosion resistance and good mechanical properties as a permanent implant. Many researchers revelled that, when it alloyed with molybdenum it shows a excellent resistance of corrosion and with high fatigue, it also have less biocompatibility and also shows some allergic reaction.

\subsection{Titanium and titanium alloy}

The main drawback of Ti and its alloy is stress shielding effect and non-degradation, but it has wide range of application because of its good mechanical strength, elasticity and cause no allergic reaction. But the further surgery is required to take out the engraft titanium alloy from the human body.

\section{Regulation of degradation rate}

To regulate the degradation rate of $\mathrm{Mg}$-based alloys, there are various method when are generally used like alloying, heat treatment and surface coating etc. To reduce the corrosion rate of the magnesium metal different elements are used in varying proportional to control the grain size, micro structure and phase distribution.[23].

\section{1. $\mathrm{Mg}$ based alloy}

The Magnesium alloy can be classified in five group on the basis of material science and nutrition. Engineering magnesium alloying with $\mathrm{Zn}, \mathrm{Ca}, \mathrm{AL}, \mathrm{Cu}, \mathrm{Sn}, \mathrm{Cd}, \mathrm{Fe}$, Th, Sr, Li, Mn, Zr, Ni, Pb, Cr, Si, Gd, Y, Sb, are very well documented [15]

\subsubsection{Nutrient elements in human}

Nutrient elements for the human body are Calcium, Zinc, Chromium, Manganese, Silica, and Tin. $\mathrm{Cr}$ and $\mathrm{Mn}$ are considered to be essential micro-nutrients but $\mathrm{Cr}$ may cause carcinogenic in humans. $\mathrm{Ca}$ is also a macronutrient present in human bone and very essential nutrient in chemical signalling with cells, with large minimal daily requirements. Sn and $\mathrm{Si}$ has not yet been 
recognized as essential for human nutrition but it believe that having some health benefits.

\subsubsection{Nutrient elements in animals and plants}

Nutrient elements in animal and plants are $\mathrm{Ag}, \mathrm{Zr}, \mathrm{Bi}$, $\mathrm{Sr}, \mathrm{Li}, \mathrm{Al}$. Their importance in human body is still to be determined but present in animals and plants. Out of these element Aluminium is well known neurotoxicant and its accumulation can cause dementia or Alzheimer disease. For the treatment of manic-depressive psychoses, Li salts are used but shows toxicity when concentration is above $2 \mathrm{mM} / \mathrm{L}$. By having the limited uses in medicinal application and show toxicity when consume in large quantity.

\subsubsection{Toxic elements}

Toxic elements are $\mathrm{Pb}$, Th and $\mathrm{Cd}$. $\mathrm{Pb}$ is highly toxic for nervous system, hematopoietic and also a nephrotoxic. Th is hazardous because of its radioactive nature. $\mathrm{Cd}$ is also recognized as a highly toxic, it effect is not only the limited up to Cardiovascular and hypertension but also on lungs, Kidneys, heart, liver, prostate, testes, heart, and liver [12].

\subsubsection{Impurities}

Impurities present in Magnesium are $\mathrm{Fe}, \mathrm{Ni}, \mathrm{Cu}$. These all elements are commonly considered as undesirable to corrosion because of their very less solid solubility in $\mathrm{Mg}$ and their presence also cause of active cathodic site, resulting galvanic corrosion [28].

\subsubsection{Others}

Others alloying element in magnesium are $\mathrm{Y}, \mathrm{Gd}, \mathrm{Sb}$, and RE. These elements are not found in human body and also not biologically essential for humans. Rare earth element having still some controversies on the biological effects. Many of the studies revealed that RE (rare earth metals) are not highly toxic, because they are directly used in chronic toxicity experiment, and therapy of cancer \& synovitis.

Table 1. Corrosion rate of $\mathrm{Mg}$ alloy.

\begin{tabular}{|l|l|l|l|}
\hline Alloy & Condition & $\begin{array}{l}\text { Corrosion } \\
\text { medium }\end{array}$ & $\begin{array}{l}\text { Corrosion } \\
\text { rate } \\
\text { mm/Year }\end{array}$ \\
\hline $\mathrm{Mg}$ & As-cast & SBF & $1.94 \sim$ \\
\hline $\mathrm{Mg}$ & & Hank's & 0.36 \\
\hline $\mathrm{Mg}$ & As rolled & SBF & 0.84 \\
\hline $\mathrm{Mg}$ & & Hank's & 0.32 \\
\hline $\mathrm{Mg}-1 \mathrm{Ca}$ & As cast & SBF & 12.56 \\
\hline $\mathrm{Mg}-1 \mathrm{Zn}$ & As cast & SBF & 1.52 \\
\hline $\mathrm{Mg}-1 \mathrm{Sn}$ & As cast & SBF & 2.45 \\
\hline $\mathrm{Mg}-1 \mathrm{Sn}$ & $\begin{array}{l}\text { Sub rapid } \\
\text { solidification }\end{array}$ & Hank's & 0.121 \\
\hline
\end{tabular}

\begin{tabular}{|c|c|c|c|}
\hline $\mathrm{Mg}-3 \mathrm{Sn}$ & & Hank's & 0.168 \\
\hline $\mathrm{Mg}-5 \mathrm{Sn}$ & & Hank's & 0.337 \\
\hline $\mathrm{Mg}-7 \mathrm{Sn}$ & & Hank's & 0.507 \\
\hline $\mathrm{Mg}-2 \mathrm{Sr}$ & As rolled & Hank's & 0.87 \\
\hline Mg-- $1 \mathrm{Mn}$ & As cast & SBF & 2.46 \\
\hline $\mathrm{Mg}-1 \mathrm{Ag}$ & As cast & SBF & 8.12 \\
\hline $\mathrm{Mg}-0.5 \mathrm{Ca}$ & & SBF & 4.08 \\
\hline $\mathrm{Mg}-0.5 \mathrm{Ca}$ & & SBF & 2.79 \\
\hline $\mathrm{Mg}-1 \mathrm{Ca}$ & & SBF & 0.66 \\
\hline $\begin{array}{l}\mathrm{Mg}-05 \mathrm{Ca}- \\
0.5 \mathrm{Zn}\end{array}$ & & SBF & 2.3 \\
\hline $\mathrm{Mg}-05 \mathrm{Ca}-1 \mathrm{Zn}$ & & SBF & 4.3 \\
\hline $\mathrm{Mg}-1 \mathrm{Ca}-1 \mathrm{Zn}$ & & SBF & 1.6 \\
\hline $\begin{array}{l}\mathrm{Mg}-0.5 \mathrm{Ca}- \\
0.5 \mathrm{Mn}\end{array}$ & & SBF & 4.2 \\
\hline $\begin{array}{l}\mathrm{Mg}-0.5 \mathrm{Ca}- \\
0.5 \mathrm{Mn}\end{array}$ & & SBF & 0.83 \\
\hline $\mathrm{Mg}-1 \mathrm{Ca}-1 \mathrm{Mn}$ & & SBF & 4.02 \\
\hline $\mathrm{Mg}-1 \mathrm{Ca}-1 \mathrm{Mn}$ & & SBF & 2.82 \\
\hline $\begin{array}{l}\mathrm{Mg}-0.5 \mathrm{Ca}- \\
0.25 \mathrm{Zn}- \\
0.25 \mathrm{Mn}\end{array}$ & & SBF & 6.9 \\
\hline $\begin{array}{l}\mathrm{Mg}-0.5 \mathrm{Ca}- \\
0.25 \mathrm{Zn}- \\
0.25 \mathrm{Mn}\end{array}$ & & SBF & 0.62 \\
\hline $\begin{array}{l}\mathrm{Mg}-1 \mathrm{Ca}- \\
0.5 \mathrm{Zn}-0.5 \mathrm{Mn}\end{array}$ & & SBF & 4.05 \\
\hline $\begin{array}{l}\text { Mg-1Ca- } \\
0.5 \mathrm{Zn}-0.5 \mathrm{Mn}\end{array}$ & & SBF & 2.09 \\
\hline Pure Mg & & Kokubo & 8.47 \\
\hline $\mathrm{Mg}-2 \mathrm{Ca}$ & & Kokubo & 6.89 \\
\hline $\mathrm{Mg}-4 \mathrm{Ca}$ & & Kokubo & 9.04 \\
\hline $\begin{array}{l}\mathrm{Mg}-2 \mathrm{Ca}- \\
05 \mathrm{Mn}-2 \mathrm{Zn}\end{array}$ & & Kokubo & 1.78 \\
\hline $\begin{array}{l}\text { Mg-2Ca- } \\
05 \mathrm{Mn}-4 \mathrm{Zn}\end{array}$ & & Kokubo & 2.27 \\
\hline $\begin{array}{l}\mathrm{Mg}-2 \mathrm{Ca}- \\
05 \mathrm{Mn}-7 \mathrm{Zn}\end{array}$ & & Kokubo & 3.98 \\
\hline $\begin{array}{l}\mathrm{Mg}-1.2 \mathrm{Zn}- \\
0.5 \mathrm{Ca}\end{array}$ & As cast & SBF & 8.2 \\
\hline $\begin{array}{l}\mathrm{Mg}-1.2 \mathrm{Zn}- \\
0.5 \mathrm{Ca}\end{array}$ & Heat treated & SBF & 4.8 \\
\hline
\end{tabular}

\subsection{Mg-based composites}

Presently investigation is going on magnesiumbased composite for its feasible use in the human body as a temporary implant. Many researches show that magnesium-based composites exhibit improved refined grain structure, mechanical strength and reduced corrosion resistance. Magnesium metal matrix composites (MMCs) having good mechanical strength, hardness, toughness and wear resistance properties, which make it as promising orthopaedic biomaterials. 
Particularly for biomaterial application several reinforcing materials including metallic powder and ceramic material like calcium polyphosphate, hydroxyapatite, tricalcium phosphate, fluorapatite, $\mathrm{ZrO}_{2}, \mathrm{Al}_{2} \mathrm{O}_{3}, \mathrm{TiO}_{2}, \mathrm{ZnO}, \mathrm{MgO}, \mathrm{TiB}_{2}, \mathrm{SiO}_{2}, \mathrm{TiC}$, TiN, Si3N4, CNTs, Zn, Sr, Zr, Sr, Ti etc., are used to produce $\mathrm{Mg}$ metal matrix composites [16].

Hydroxyapatite (HA) is one of the inorganic compounds that having a biological importance to human bones (make up 50\% by vol) and teeth. Hence HA is a biocompatible material. Hydroxyapatite ceramic powder exhibits excellent biocompatibility, bioactivity, and osseointegration. Since HA stimulates bone ingrowth it enhanced osseointegration. Due to increase in the biomineralization by adding the HAp to magnesium the resultant $\mathrm{Mg}$ substrate, which act as a nucleating site for mineral deposition, will increase the corrosion resistance in physiological environment and hence decrease the degradation rate. It has been proved by the researcher that the mechanical strength, corrosion and bio-properties of $\mathrm{Mg}$ based bio-composite will be enhanced by adding the HAp in magnesium-based composite [28].

When we use the nano reinforcement instead of micro level reinforcement in magnesium composite, we get relatively good mechanical properties like mechanical strength, yield strength and ductility due to increase in wetting property. The recent development of reinforcement is by using the naturally derived nano HAp to develop magnesium metal matrix composite, Fish bone is recently used in some research.

Table 2. Corrosion resistance of $\mathrm{Mg}$ composite.

\begin{tabular}{|c|c|c|}
\hline Composites & $\begin{array}{l}\text { Effect on corrosion resistance by } \\
\text { adding HAp on } \mathrm{Mg} / \mathrm{Mg} \text { alloy }\end{array}$ & Medium \\
\hline $\begin{array}{l}\text { AZ91D-20 } \\
\text { wt.\% HA }\end{array}$ & $\begin{array}{l}1.25-0.16 \mathrm{~mm} / \text { year for AZ91D-20 } \\
\text { wt.\% HA composite, although no } \\
\text { data were reported for bare AZ91D }\end{array}$ & $\begin{array}{l}\text { Artificial } \\
\text { sea water }\end{array}$ \\
\hline $\begin{array}{l}\mathrm{Mg}-\mathrm{HA} \\
(10,20,30 \\
\text { wt. } \%)\end{array}$ & $\begin{array}{l}\text { Decrease the corrosion resistance } \\
\text { of } \mathrm{Mg} \text { by } \sim 31 \% \text { by adding } 10 \mathrm{wt} \% \\
\text { HA }\end{array}$ & SBF \\
\hline $\begin{array}{l}\text { (Mg-Zn- } \\
\mathrm{Zr})-1 \text { wt.\% } \\
\text { nHA }\end{array}$ & $\begin{array}{l}\text { Polarization resistance improved } \\
\text { by } \sim 57 \% \text { and } E \text { corr was also } \\
\text { shifted towards the positive side }\end{array}$ & SBF \\
\hline $\begin{array}{l}\mathrm{Mg}-\mathrm{HA} \\
(10,20 \\
\text { wt. } \%)\end{array}$ & $\begin{array}{l}\text { Addition of } 10 \% \text { HA has shown } \sim \\
10 \% \text { higher corrosion resistance as } \\
\text { compared to pure } \mathrm{Mg} \text { and after } \\
\text { PEO treatment of composite has } \\
\text { improved the corrosion resistance } \\
\text { of } \mathrm{Mg}-10 \mathrm{HA} \text { by } \sim 250 \%\end{array}$ & SBF \\
\hline $\begin{array}{l}(\mathrm{Mg}-3 \mathrm{Zn}- \\
0.5 \mathrm{Zr})-\mathrm{HA} \\
(0,0.5,1 \\
\text { and } 1.5 \\
\text { wt.\%) }\end{array}$ & $\begin{array}{l}\text { Ecorr value shifted by } \sim 11 \% \\
\text { towards }+ \text { ve side by adding } 1 \% \text { wt } \\
\text { HA in alloy }\end{array}$ & SBF \\
\hline $\begin{array}{l}\mathrm{Mg}-\mathrm{HA}(5, \\
8,10 \text { and } \\
15 \text { wt. } \%)\end{array}$ & $\begin{array}{l}\text { Ecorr value shifted by } 95 \% \\
\text { towards the +ve side, with } \sim 10 \\
\text { times decrease in the corrosion } \\
\text { current density by adding } 10 \mathrm{wt} \% \\
\text { HA }\end{array}$ & $\begin{array}{l}3.5 \% \\
\mathrm{NaCl} \\
\text { solution }\end{array}$ \\
\hline
\end{tabular}

\begin{tabular}{|c|c|c|}
\hline $\begin{array}{l}(\mathrm{Mg}-\mathrm{Zn}- \\
\mathrm{Y})-0.5 \\
\text { wt. } \% \mathrm{HA}\end{array}$ & $\begin{array}{l}\text { Improvement in the corrosion rate } \\
\text { to } \sim 62 \% \text { by adding } 0.5 \mathrm{wt} \% \mathrm{HA}\end{array}$ & SBF \\
\hline $\begin{array}{l}(\mathrm{Mg}-3 \mathrm{Zn})- \\
\mathrm{HA}(0,2 \\
5,10 \text { wt. } \% \\
\text { HA) }\end{array}$ & $\begin{array}{l}\text { Improvement in the corrosion } \\
\text { resistance to } \sim 42 \% \text { by adding } 5 \\
\text { wt } \% \text { HA }\end{array}$ & SBF \\
\hline $\begin{array}{l}(\mathrm{Mg}-2 \mathrm{Zn}- \\
0.5 \mathrm{Sr})-\mathrm{HA} \\
(0,0.1,0.3 \\
\text { wt.\%) }\end{array}$ & $\begin{array}{l}\text { Increase in the corrosion resistance } \\
\text { about } \sim 44 \% \text { by adding } 0.3 \mathrm{wt} \% \\
\text { HA in alloy }\end{array}$ & SBF \\
\hline $\begin{array}{l}(\mathrm{Mg}-5 \mathrm{Zn}- \\
0.3 \mathrm{Ca})-\mathrm{HA} \\
(0,1,2.5,5 \\
\text { wt. } \% \text { HA })\end{array}$ & $\begin{array}{l}\text { Decrease in corrosion current } \\
\text { density by } \sim 66 \% \text { after addition of } \\
1 \text { wt. } \% \text { HA }\end{array}$ & SBF \\
\hline $\begin{array}{l}(\mathrm{Mg}-1 \mathrm{Zn}- \\
1 \mathrm{Ca})-\mathrm{HA} \\
(0,13 \\
\text { wt. } \% \text { HA })\end{array}$ & $\begin{array}{l}\text { Increase in corrosion resistance by } \\
\sim 76 \% \text { after adding } 1 \mathrm{wt} \% \mathrm{HA} \text { in } \\
\text { alloy }\end{array}$ & (PBS) \\
\hline $\begin{array}{l}\mathrm{Mg}-15 \\
\text { wt. } \% \text { HA }\end{array}$ & $\begin{array}{l}\text { Decrease in corrosion current } \\
\text { density about } \sim 57 \% \text { by adding } 15 \\
\text { wt } \% \mathrm{HA} \text { in } \mathrm{Mg}\end{array}$ & SBF \\
\hline AZ31-nHA & $\begin{array}{l}\text { Increase in corrosion resistance } \\
\text { about } \sim 72 \% \text { by adding nHA in } \\
\text { alloy }\end{array}$ & SBF \\
\hline $\begin{array}{l}\text { Mg-HA }(5, \\
10,15 \\
\text { wt. } \%)\end{array}$ & $\begin{array}{l}\text { Decrease in the corrosion current } \\
\text { density about } \sim 60 \% \text { by adding } 10 \\
\text { wt } \% \text { HA }\end{array}$ & SBF \\
\hline $\begin{array}{l}\mathrm{Mg}-2.5 \\
\text { wt.\% HA }\end{array}$ & $\begin{array}{l}\text { Negligible changes in the } \\
\text { corrosion resistance by adding } 2.5 \\
\% \text { wt HA in Mg by FSP process }\end{array}$ & (DPBS) \\
\hline $\begin{array}{l}\text { ZE41-fish } \\
\text { bone } \\
\text { derived HA }\end{array}$ & $\begin{array}{l}\text { Increased corrosion resistance } \\
\text { about } \sim 52 \% \text { by adding fish bone } \\
\text { derived HA }\end{array}$ & $\begin{array}{l}\text { Ringer's } \\
\text { Solution }\end{array}$ \\
\hline
\end{tabular}

\section{Conclusion}

Magnesium as a "biodegradable" metal is the most emerging as promising metal for bone implants. Presently, the research in the field of biomedical especially for the Mg-based alloys and its composite are in demand. It is believed that magnesium-based alloy possesses the similar modulus of elasticity and very good biocompatibility. Although, they are degraded faster than development of new bone. a considerable efforted has been made continuously for developing the new metallic implants with matched biodegradability and mechanical properties as bone repair. For example, a series of Magnesium MMC alloy such as LAE442, WE43, and ZEK100 etc., has been developed and it shows improvement in corrosion resistance. Addition of HAp used to make the $\mathrm{Mg}$ based composite reduce the ductility and yield strength of implant, but at the same time improve the corrosion resistance. These $\mathrm{Mg}$ based composites used as bone replacement and body implants as it provides great strength-to-weight ratio as well as bio-compatibility and bio-degradability. 


\section{References}

1. S. Jaiswal, A. Dubey, Lahiri, J.I.I. , 99, 303 (2019).

2. G. Hill, JBI Libr Syst Rev 8,1 (2010)

3. F. Moussy, J. Biomed. Mater. Res. 94,1001 (2010)

4. CP Stumpf, Biomaterials in dental ceramics, topics in mining, metallurgy and materials engineering. Springer, Berlin, 9 (2013)

5. YF Zheng, XN Gu, F, Witte, Mater Sci Eng, R 77,1 (2014)

6. S. Katti, I.R. Lakshmi, C.T. Laurecin, Adv Drug Deliv Rev 54,933 (2002)

7. M. Vert, J. Maudtui, S. Li, Biomaterials 15,1209 (1994)

8. X. Cai, H. Tong, J. H , Acta Bio- mater, 5,2693 (2009)

9. C. EdiTanase, Mater Sci Eng, 40, 242

10. S.Y. Park,Tissue Eng Part A 16, 1271 (2010)

11. A.J. Mieszawska, Acta Biomater, 7, 3036 (2011)

12. Y. Wang, Biomaterials, 9, 415 (2008)

13. S. Terasaka, Y. Iwasaki, T. Uchida, Neurosurgery 58,134 (2006)

14. F. Witte, N. Hort, K.U. Kainer, Curr Opin Solid State Mater Sci 12,63 (2008)

15. A.K. Khanra, H.C. Jung, K.S. Hong, K.S. Shin , Bull Mater Sci 33,43 (2010)

16. Y.W. Gu, N.H. Loha, S.B. Tor, P. Cheang , Biomaterials, 23,37 (2002)

17. L.G. Yu, K.A. Khor, P., Biomaterials 24, 2695 (2003)

18. N.S. Manam, Harun, DNA Shri, J Alloys Compound 701,698 (2017)

19. H. Y. Ha, J. Y. Kang, S. G. Kim, B. Kim, S. S.Park, C. D. Yim, B. S. You, , Corrosion Science, 82, 369 (2014)

20. C. Zhao, F. Pan, S. Zhao, H. Pan, K. Song, A. Tang, Materials \& Design, 70, 60 (2015)

21. C. Zhao, F. Pan, S. Zhao, H. Pan, K. Song, A. Tang, Materials Science and Engineering: C,54, 245 2015)

22. X. Liu, D. Shan, Y. Song, R. Chen, E. Han, Electrochimica acta,56, 2582 (2011)

23. H. Y. Ha, J. Y. Kang, J. Yang, C. D. Yim, B. S You, Corrosion Science, 102, 355 (2016)

24. A. K. Khanra, H. C. Jung, S. H. Yu, K. S. Hong, K. S. Shin, Bulletin of Materials Science,33, 43 (2010)

25. X. Gu, W. Zhou, Y. Zheng, L. Dong, Y. Xi, D. Chai, Materials Science and Engineering: C,30, 827 (2010)

26. R. Viswanathan, N. Rameshbabu, S. Kennedy, D. Sreekanth, K. Venkateswarlu, M. Sandhya Rani, V. Muthupandi, In Materials Science Forum (Vol. 765, pp. 827-831). Trans Tech Publications Ltd.(2013)
27. C. Ma, L. Chen, J. Xu, A. Fehrenbacher, Y. Li, F. E Pfefferkorn, X. Li, J.B.M.R (2013)

28. W.Ding, , Regenerative biomaterials,3, 79 (2016)

29. M. Esmaily, J. E. Svensson, S. Fajardo, N. Birbilis, G. S. Frankel, S. Virtanen, L. G. Johansson, Progress in Materials Science,89, 92 (2017) 